\title{
MATA PELAJARAN AKIDAH AKHLAK SEBAGAI SARANA PEMBIASAAN SIKAP TAWADHU
}

\author{
Taufiqur Rohman \\ Institut Aagama Islam Negeri SALATIGA \\ Email: rohmantaufiqur93@gmail.com
}

\begin{abstract}
ABSTRAK
Penelitian ini membahas tentang Mata pelajaran akidah akhlak sebagai sarana pembiasaan sikap tawadhu bertujuan untuk mengetahui tentang mata pelajaran akidah akhlak sebagai sarana pembiasaan sikap tawadhu. Metode yang digunakan untuk menyusun penelitian ini adalah field research (penelitian lapangan), teknik pengunpulan data ini diperoleh melalui wawancara, observasi dan dokumentasi. Dengan metode tersebut peneliti melakukan wawancara langsung terhadap kepala madrasah, guru dibagian kurikulum, guru, peserta didik dan menggali data melalui dokumentasi madrasah. Hasil penelitian menunjukkan bahwa (1) muatan nilai tawadhu dalam pembelajaran akidah akhlak di MI adalah hormat dan patuh kepada guru dan orang tua, rendah hati, adab kepada sesama manusia, terbiasa melaksanakan ibadah, saling menghargai, rajin belajar. (2) Pembiasaan yang ditanamkan guru untuk membentuk sikap tawadhu adalah

Membaca Al-Qur'an, Membaca Asmaul Husna dan Sholat dhuha dan dhuhur berjamaah (3) Dampak dari hasil pembiasaan sikap tawadhu dalam pembelajaran akidah akhlak yaitu timbulnya sikap sopan santun, rendah hati, hormat dan patuh kepada guru dan orang tua, rajin belajar serta terbiasa melaksanakan ibadah. Sikap yang belum muncul dari peserta didik adalah saling menolong, berpakaian rapi dan sederhana.
\end{abstract}

Kata Kunci : Akidah Akhlak, Pembiasaan, Nilai Tawadhu

\section{ABSTRAC}

This research discusses the subjects of moral creed as a means of habituation to aim tawadhu aims to find out about the subjects of moral creed as a means of habituation of tawadhu attitude in the upper classes at MI Ma'arif Mangunsari Salatiga City. The method used to arrange this research is field research, data collection techniques were obtained through interviews, observation and documentation. The method the researcher conduct directed by use interviews to the headmaster of madrasah, coordinator of curriculum, teachers, students and founding datas through madrasah documentation. The results showed that (1) the content of tawadhu values in the learning of moral conduct in MI is respectful and obedient to teachers and parents, humble, courteous to fellow humans, accustomed to performing worship, mutual 
respect, study hard. (2) The habit that is instilled by the teacher to form the attitude of tawadhu is reading Al-Qur'an, reading asmaul husna and dhuha prayers and dhuha congregation (3) The impact of the results of habituation attitudes in the learning of moral creed namely the emergence of courtesy, humility, respect and obedience to teachers and parents, diligent learning and accustomed to performing worship. Attitudes that have not arisen from students are mutual help, neatly dressed and simple.

Keyword: Akidah Akhlak, habituation, the Respect value

\section{A. Pendahuluan}

Penyelenggaraan pendidikan yang mengedepankan akhlak menjadi satu hal yang mutlak dilakukan di jenjang pendidikan manapun, khususnya di jenjang pendidikan dasar. Hal ini sangat beralasan karena pendidikan dasar adalah pondasi utama bagi tumbuh kembang generasi muda Indonesia. Pemahaman yang mendalam dari praktisi pendidikan terhadap konsep pendidikan yang mengedepankan akhlak dan karakter menjadi taruhan bagi keberhasilan pendidikan akhlak di setiap satuan pendidikan. ${ }^{1}$ Di era globalisasi saat ini banyak masyarakat yang mulai sadar akan pentingnya pendidikan Islam, sebab dengan pendidikan Islam dapat membentuk akhlakul karimah.

Pendidikan yang berdasarkan Islam merupakan pendidikan yang dipahami dan dikembangkan berdasarkan ajaran yang bersumber pada Al-Qur'an dan Hadits. ${ }^{2}$ Pendidikan Islam berusaha menyajikan pola pendidikan yang dapat mengcover semua yang dibutuhkan peserta didik, saat ini banyak berdiri sekolah Islam yang menerapkan berbagai macam pola pendidikan demi terwujudnya insan yang mulia.

Menanamkan nilai tawadhu' (rendah hati) ternyata mampu meredam terjadinya gesekan-gesekan yang terjadi pada peserta didik disekolah yang bisa saja muncul. Beberapa kasus misalnya peserta didik MI sering berkelahi antar temannya sendiri, belum bisa menghargai pendapat orang lain. Dilihat dari zaman- ke zaman seiring berjalannya waktu peserta didik sekarang cenderung kurang memperhatikan adab tata krama dan sopan santun,

'Zulnuraini, Pendidikan Karakter, "Konsep, Implementasi Dan Pengembangannya di Sekolah Dasar Di Kota Palu" Jurnal DIKDAS, Vol.1, No. 1, September 2012, 1-17.

${ }_{2}^{2}$ Faqih, Khaerul, Nilai-nilai Pendidikan Akhlak dan Tasawuf dalam Kitab Nashoihul Ibad Karya Syaikh Nawawi Albantani dan Implementasinya pada Pondok Pesantren Tradisional, Jurnal Aksioma Ad-Diniyah, Vol. 6, No. 2, 2018, 150-182. 
kurang menghargai satu sama lain dan sudah mengalami kemerossotan moral yang semakin melanda di masyarakat. ${ }^{3}$

Pernyataan ahmad syahroni pemerhati pemuda menyampaikan keprihatinannya atas tindakan kekerasan yang dilakukan belakangan ini seperti pelemparan air keras, pembajakan bus, membolos sekolah, merokok ditempat umum dalam usia sekolah dan sebagainya. Menurut roni berdasarkan statistik di berbagai belahan dunia, diantaranya data badan sensus Amerika bahwa 60 persen dari populasi remaja terpapar tindakan kekerasan baik yang dilakukan oleh mereka sendiri (tawuran, aksi kriminal) ataupun oleh orang lain seperti pemerkosaan tindak kekerasan dan sebagainya. Roni memotret data Pusat Pengendalian Gangguan Sosial DKI Jakarta bahwa pada 2009 terdapat 0,08 persen atau 1.318 dari 1.647.835 siswa SD, SMP, SMA di Jakarta Pusat dan Daerah Pulau Jawa terlibat tawuran dan angka ini meningkat dari tahun ke tahun. Roni mengungkapkan bahwa kenakalan ini terjadi karena remaja usia sekolah memiliki karakter labil, egois, dan mengedepankan kesenangan, di atas tindakan produktif dan positif. Ini kemudian sesuai dengan hasil penelitian yang mengungkapkan bahwa remaja usia sekolah dari SD sampai SMA fase yang paling berbahaya dalam kehidupan seseorang. Dan $65 \%$ memiliki masalah di keluarga seperti masalah keuangan, masalah, perceraian, orang tua, dan anggota keluarga meninggal. ${ }^{4}$ Hal ini harus ditanggulangi secara dini untuk meminimalisir terjadinya kekerasan, kenakalan remaja yang terjadi di masyarakat.

Untuk itu penting untuk menggali nilai tawadhu dalam pembelajaran akidah akhlak melalui kurikulum 2013 yang ada di Madrasah Ibtidaiyah. Penelitian ini bertempat di MI Ma'arif Mangunsari khususnya dikelas atas yaitu kelas 4, 5 dan 6 .

\footnotetext{
3 Dadan Sumara, Sahadi Sumaedi, Meilani Budiarti Santoso, Kenakalan Remaja dan Penanganannya. Jurnal Penelitian dan PPM, Vol. 4, No. 2, 2017, 346-347.

${ }^{4}$ Nunung Unayah dan Muslim Sabarisman, Fenomena Kenakalan Remaja dan Kriminalitas The Phenomenon Of Juvenili Delinquency And Criminality, Sosio Informa, Vol 1, No. 02, Mei-Agustus, 2015, 122-123.
} 
Dari paparan semua di atas maka peneliti mengambil judul penelitian sebagai berikut Mata Pelajaran Akidah Akhlak Sebagai Sarana Pembiasaan Sikap Tawadhu di kelas atas MI Ma'arif Mangunsari Kota Salatiga.

\section{B. Metode Penelitian}

\section{Pendekatan Penelitian}

Penelitian adalah suatu kegiatan atau proses sistematis untuk memecahkan masalah yang dilakukan dengan menerapkan metode ilmiah. ${ }^{5}$ Ditinjau dari tempatnya, penelitian ini termasuk penelitian lapangan (Field Research), karena data sepenuhnya digali dari lapangan. Pendekatan yang digunakan adalah pendekatan kualitatif, adalah prosedur penelitian yang menghasilkan data deskriptif berupa kata-kata tertulis atau lisan dari orang-orang dan perilaku yang dapat diamati. ${ }^{6}$

\section{Lokasi Penelitian}

Penelitian ini dilakukan di MI Ma'arif Mangunsari Kota Salatiga masyarakat yang mayoritas muslim antusias terhadap adanya madrasah ini. Hal ini terbukti bahwa mayoritas peserta didik bertempat tinggal di sekitar daerah se-kota salatiga karena madrasah ini tergolong madrasah yang berkembang akan mengalami kemajuan.

\section{Jenis Data}

Jenis data yang dibutuhkan dalam penelitian ini adalah data primer dan data sekunder. Data primer yaitu data yang diperoleh melalui hasil wawancara dan observasi kegiatan pembelajaran akidah akhlak yang berlangsung di MI Ma'arif Mangunsari sedangkan sumber data tambahan (sekunder) yang digunakan dalam penelitian ini terdiri dari

\footnotetext{
${ }^{5}$ Emzir, Metodologi Penelitian Pendidikan Kuantitatif \& Kualitatif, Jakarta: PT. Raja Grafindo Persada, 2010, 1.
}

${ }^{6}$ Lexy J Moleong, Metodologi Penelitian Kualitatif, Bandung: Rosda Karya, 2013, 3. 
dokumen data umum seperti gambaran umum MI Ma'arif Mangunsari serta data khusus seperti kegiatan pembelajaran dan penelusuran pustaka.

\section{Teknik Pengumpulan Data}

\section{a. Metode Observasi (Pengamatan)}

Metode Observasi adalah suatu metode penelitian yang digunakan dengan jalan pengamatan suatu obyek dengan seluruh indra. ${ }^{7}$ Sebuah pengamatan terhadap fenomena sosiologi-keagamaan selama beberapa waktu tanpa mempengaruhi fenomena yang diobservasi, dengan mencatat, merekam, memotret fenomena tersebut guna penemuan data analisis. ${ }^{8}$ Menggunakan metode observasi agar dapat mengamati dan mencatat data yang didapat tentang kondisi geografis serta pembelajaran akidah akhlak untuk memperoleh informasi tentang proses pembelajaran dikelas.

b. Metode Wawancara (Interview)

Wawancara atau interview adalah pengumpulan data dengan cara bertanya langsung kepada informan untuk mendapat data dan informasi yang akurat. ${ }^{9}$ Metode ini digunakan untuk mengumpulkan data melelui wawancara kepada:

1) Kepala Madrasah, yaitu untuk mengetahui dan menggali mengenai muatan materi dan pembiasaan guru untuk membentuk sikap nilai tawadhu dalam pembelajaran akidah akhlak di kelas atas serta informasi lain dalam wewenang dan tanggung jawabnya.

2) Sie Kurikulum untuk mengetahui muatan nilai tawadhu dalam pembelajaran akidah akhlak di kelas atas.

\footnotetext{
${ }^{7}$ Suharsimi Arikunto. Prosedur Penelitian. Jakarta: Bina Aksara,1998, 146.

8 Tobroni, Imam Suprayogo. Metodologi Penelitian Sosiologi-Agama, Cet. II, Bandung: PT. Remaja Rosdakarya, 2003, 63.

${ }^{9}$ Syamsuddi Sahiron (ed), Metodologi Penelitian Qur'an dan Hadis, Yogyakarta:TH Press, 2007, 60.
} 
3) Guru untuk mendapatkan informasi tentang teknik pelaksanaan strategi yang dipakai, hambatan hambatan yang ditemui dalam internalisasi nilai tawadhu'.

4) Peserta didik, untuk mengetahui kegiatan sikap tentang nilai tawadhu, dan halhal yang berhubungan dengan peserta didik sebelum maupun sesudah di ajarakan oleh guru.

c. Teknik Dokumentasi

Teknik Dokumentasi menurut Irwan adalah teknik pengumpulan data yang ditujukan kepada subyek penelitian, dokumen yang diketik dapat berupa berbagai macam, tidak hanya dokumen resmi. ${ }^{10}$ Dokumen yang dicari adalah muatan mata pelajaran akidah akhlak, foto kegiatan pembelajaran, bentuk dokumen.

\section{Tinjauan Teori}

1. Akidah Akhlak

Secara etimologis (Lughatan) akhlaq (bahasa arab) adalah bentuk jamak dari "khuluq" yang berarti perangai, budi pekerti, tingkah laku atau tabiat. Berakar dari kata "khalaq" yang artinya menciptakan seakar dengan kata khaliq (pencipta), makhluk (yang diciptakan) dan khalq (pencipta). Akhlak adalah segala sesuatu yang telah tertanam atau terpatri dalam diri seseorang dengan kuat, yang akan melahirkan perilaku atau perbuatan yang tanpa melalui pemikiran atau renungan terlebih dahulu. ${ }^{11}$ Akhlak merupakan perbuatan atau perilaku yang dibiasakan dalam kehidupan sehari-hari, perbuatan tersebut mengalami pengulangan dan berubah menjadi kebiasaan. ${ }^{12}$

Dengan demikian aqidah akhlak adalah sesuatu yang diucapkan dengan lisan, diyakini dalam hati, dan dilakukan dengan perbuatan tanpa adanya keraguan sedikitpun. seperti pendapat yang pertama menurut Rosihon anwar dkk, bahwa aqidah ini sudah mengakar dalam hati. Selain percaya juga harus diucapkan dengan lisan, dan dibuktikan

\footnotetext{
${ }^{10}$ Sukandarrumidi, Metodologi Penelitian Praktis, Yogyakarta: Teras, 2006, 100-101.

${ }^{11}$ Ilyas, Yunahar, Kuliah Akhlaq, Yogyakarta: Lembaga Pengkajian dan Pengamalan Islam LPPI, 2001, 1-2.

${ }^{12}$ Asren Nasution, Membangun Karakter Bangsa Bercermin pada Sosok Jenderal Besar Soedirman, Jakarta: Prenada, 2012, 32.
} 
dengan perbuatan. ${ }^{13}$ Pendidikan agama Islam yang memuat akidah akhlak memiliki peranan yang sangat penting dan strategis dalam upaya membentuk perilaku yang baik. ${ }^{14}$

2. Ruang Lingkup pembelajaran Akidah akhlak dalam kurikulum 2013

Ruang lingkup akidah akhlak di Madrasah Ibtidaiyah : a) aspek kaidah keimanan yang meliputi kalimat toyyibah, asmaul husna, Iman kepada Allah, Iman kepada Malaikatmalaikat Allah yang tergabung dalam rukun iman. b) aspek Akhlak meliputi: Pembiasaan akhlakul karimah (mahmudah) dan menghindari akhlak tercela (mazmumah). c) aspek adab yang meliputi adab ke sesama teman dan adab kepada lingkungan. d) kisah teladan sahabat sahabat nabi.

3. Pembiasaan

Secara etimologi pembiasaan asal katanya adalah biasa. Dalam kamus bahsa Indonesia biasa adalah lazim atau umum, seperti sedia kala, sudah merupakan yang tidak terpisahkan dari dari kehidupan sehari-hari. Dengan adanya prefiks pe- dan -an menunjukkan arti proses. Sehingga pembiasaan dapat diartikan dengan proses membuat sesuatuatau seseorang menjadi terbiasa. Dalam kaitannya dengan metode pengajaran dalam pendidikan Islam dapat dikatakan bahwa pembiasaan adalah sebuah cara yang dapat dilakukan untuk membiasakan peserta didik berfikir, bersikap dan bertindak sesuai dengan tuntunan ajaran agama Islam. ${ }^{15}$

4. Strategi yang ditanamkan pada peserta didik

Secara umum, strategi merupakan garis besar untuk bertindak dalam usaha untuk mencapai sasaran yang telah ditentukan dan sebagai pola-pola umum kegiatan guru beserta pesera didik dalam mewujudkan kegiatan belajar mengajar untuk mencapai tujuan yang telah digariskan. Adapun beberapa strategi yang dapat digunakan oleh guru dalam menanamkan nilai-nilai keagamaan antara lain: ${ }^{16}$

\footnotetext{
${ }^{13}$ Ilyas, Yunahar, Kuliah Aqidah, Yogyakarta: Lembaga Pengkajian dan Pengalaman Islam LPPI, $2000,6$.

${ }^{14}$ Fachri, Moch. "Urgensi Pendidikan Agama Islam dalam Pembentukan KarakterBangsa”, At-turas, Volume 1, Number 1 (Januari-Juni 2014), 167.

15 Armai, Arief. Pengantar Ilmu dan Metodologi Pendidikan Islam, Jakarta: Ciputat Pers, 2002. 110.

16 Ansori, Ahmad Muhajir Strategi Penanaman Nilai-nilai Pendidikan Islam Pada Peserta Didik, Jurnal Pusaka Media Kajian dan Pemikiran Islam LP3I IAI Al-Qolam, (2016) 8 : 14-32.
} 
a. Keteladanan, Keteladanan dalam bahasa arab disebut uswah, iswah, qudwah, qidwah yang berarti perilaku baik yang dapat ditiru oleh orang lain. ${ }^{17}$

b. Metode pembiasaan adalah suatu cara yang dapat dilakukan untuk membiasakan anak berfikir, bersikap, bertindak sesuai dengan ajaran agama Islam.

c. Metode nasihat ini merupakan metode fleksibel yang dapat digunakan oleh para pendidik. Kapanpun dan di manapun setiap orang yang melihat kepada kemungkaran atau melanggar norma-norma adat kebiasaan suatu kelompok, maka minimal yang bisa kita lakukan adalah dengan cara menasihati.

d. Tsawāb (Hukuman) Salah satu upaya mewujudkan tujuan pendidikan adalah perlunya ditanamkan sikap disiplin dan tanggung jawab yang besar dalam proses pembelajaran.

5. Pengertian Tawadhu'

Sikap tawadhu' adalah kebalikan dari sikap sombong. Tawadhu' adalah bagian dari akhlak mulia, sedangkan kesombongan termasuk akhlak yang tercela. ${ }^{18}$ Tawadhu' adalah sikap rendah hati, namun tidak sampai merendahkan kehormatan diri dan tidak pula memberi peluang orang lain untuk melecehkan kemuliaan diri. Menurut Nasirudin, tawadhu' secara istilah adalah sebagai berikut: ${ }^{19}$

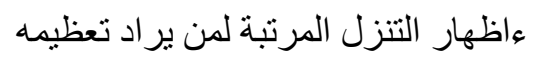

Memperlihatkan kedudukan yang rendah terhadap orang yang diagungkan.

$$
\text { التو اضع هو الاستسلام للحق وترك الاعتر اض في الحكم }
$$

Tawadhu' adalah menyerah pada kebenaran dan meninggalkan perlawanan dalam keputusan.

Pengertian pertama yaitu menunjukkan bahwa tawadhu' berarti menunjukkan kerendahan, kesederhanaan kepada orang lain, meskipun sebenarnya orang yang rendah

\footnotetext{
${ }^{17}$ Armai Arief, Pengantar Ilmu dan Metodologi Pendidikan Islam, Jakarta: Ciputat Press, 2002, 112 .

18 Al-Hasyim Abdul Mun 'im, Akhlak Rasul Menurut Bukhari Muslim, Jakarta: Gema Insani, 2009, 12.

${ }^{19}$ Nasirudin, Akhlak Pendidik Upaya Membentuk Kompetensi Spiritual dan Sosial, Semarang: CV Karya Abadi Jaya, 2015. 133-134.
} 
hati tersebut statusnya lebih tinggi daripada orang lain. Orang yang tawadhu' senantiasa merendahkan hatinya dan santun terhadap orang lain, tidak merasa dirinya memiliki nilai lebih dibandingkan orang lain. Pengertian kedua menunjukkan bahwa orang yang tawadhu' mau menerima kebenaran dari siapapun yang menyampaikan, atau mau menerima kebenaran tanpa melihat siapa yang berbicara.

Rendah hati berbeda dengan rendah diri. Orang yang rendah hati tidak memandang dirinya lebih dari orang lain, sementara orang yang sombong menghargai dirinya secara berlebihan. Rendah hati tidak sama dengan rendah diri, karena rendah diri berarti kehilangan kepercayaan diri. Sekalipun dalam praktiknya orang yang rendah hati cenderung merendahkan dirinya dihadapan orang lain, tapi sikap tersebut bukan lahir dari rasa tidak percaya diri. ${ }^{20}$ Tawadhue mempunyai dua makna, yaitu menerima kebenaran yang datangnya dari siapa saja dan mampu menjalin interaksi dengan semua manusia. Orang yang tawadhu' akan menerima kebenaran yang datangnya dari siapapun, baik orang itu miskin ataupun kaya, terhormat ataupun sederhana, kuat maupun lemah, dari temanya sendiri atau bahkan dari musuhnya dan memiliki sikap penuh kasih sayang serta lemah lembut terhadap siapapun. ${ }^{21}$

Sikap tawadhu' yang dimiliki seseorang dapat dilihat dari perilakunya seharihari. Adapun indikator bentuk perilaku tawadhu': a) berbicara santun; b) rendah hati; c) suka menolong; d) patuh terhadap orang tua; e) Patuh terhadap nasihat guru; f) rajin belajar; g) berpakaian rapi dan sederhana. ${ }^{22}$

\section{Pembahasan}

\section{Muatan Nilai Tawadhu Dalam Pembelajaran Akidah Akhlak di Kelas Atas MI Ma'arif Mangunsari}

\footnotetext{
${ }^{20}$ Nasirudin, Akhlak Pendidik Upaya Membentuk Kompetensi Spiritual dan sosial...184.

${ }^{21}$ Amrul Khalid, Semulia Akhlak Nabi, Solo: Aqwam, 2006, 83-84.

${ }^{22}$ Syekh ahmad ibnu Athaillah dalam purnama Rozak, Indikator tawadhu dalam keseharian, Jurnal Madaniyah, Volume 1 Edisi XII, Januari 2018, 181.
} 
Muatan nilai tawadhu' merupakan bagian yang sangat penting dikarenakan memuat beberapa indikator dalam pembelajaran, terkait muatan materi tentang nilai tawadhu sudah tertera dibuku paket akidah akhlak kurikulum 2013. Ada beberapa muatan nilai tawadhu' di MI Ma'arif Mangunsari seperti yang diungkapkan oleh SR kepala madrasah MI Ma'arif Mangunsari:

“Muatan nilai tawadhu' yang berada di MI Ma'arif Mangunsari ini sebenarnya ada disilabus Akidah akhlak mas, khususnya kelas atas 4, 5 dan 6 MI dimana disitu ada muatan-muatan yang mengandung aspek ketuhanan (tauhid), aspek akhlak, aspek adab kesesama teman, sosial, sampai keranah lingkungan. ${ }^{23}$

Muatan materi tawadhu' yang ada MI Ma'arif Mangunsari ini terangkum dalam materi pembelajaran akidah akhlak untuk dijadikan sebagai dasar pembentukan akhlak yang baik. Hal ini selaras dengan yang dikatakan oleh ibu FZ sebagai bagian kurikulum MI Ma'arif Mangunsari:

"Muatan nilai tawadhu yang diajarkan bergaul dengan semua teman saling tolong menolong, ringan tangan membantu orang lain teman, guru yang perlu bantuan, rendah hati pada gurunyaagar dapat mengambil manfaat ilmunya. ${ }^{24}$

Oleh sebab itu, muatan materi yang mengacu pada nilai tawadhu diharapkan dapat digunakan sebagai sarana pembelajaran untuk menanamkan sopan santun dalam berbicara, patuh dan hormat kepada orang tua dan guru, akhlak kesesama peserta didik di madrasah baik. Dari kelas atas 4 sampai kelas 6 memuat beberapa materi yang bermuatan nilai tawadhu'. Diantaranya, muatan nilai tawadhu di kelas 4 yaitu peserta didik mempelajari indahnya berperilaku terpuji 1 (hormat dan patuh kepada orang tua dan guru), indahnya berperilaku terpuji 2 (tabah dan sabar dalam menghadapi cobaan melalui kisah siti masyitoh), Asmaul husna (As-salam, Al-Latif) yang mana mengajarkan peserta didik untuk membiasakan mengucapkan salam serta bersikap ramah lemah lembut dalam bertutur kata dengan orang tua, guru, teman dan antara sesama. Indahnya berperilaku

${ }^{23}$ Wawancara dengan SR kepala madrasah MI Ma'arif Mangunsari pada tanggal 8 Februari 2020.

${ }^{24}$ Wawancara dengan FZ bagian kurikulum MI Ma'arif Mangunsari pada tanggal 3 Februari 2020. 
terpuji 4 (berperilaku terpuji ketika bertamu dan berperilaku terpuji terhadap teman dalam kehidupan sehari-hari). ${ }^{25}$

Sementara itu materi materi kelas 5 yang berkaitan dengan nilai tawadhu' yaitu mari membina keharmonisan dengan tetangga dan masyarakat yang menjelaskan tentang menghormati tetangga, saling menyayangi, hidup bermasyarakat yang baik dengan mengedepankan sikap lemah lembut, memupuk sikap toleransi hormat menghormati dengan seluruh anggota masyarakat. ${ }^{26}$ Untuk materi kelas 6 ada materi tentang Indahnya melantunkan kalimat toyyibah (istighfar), mengenal Allah melalui asmaul husna ( $A l$ ghafur, Al-Afwu, As-sabur, Al-Halim), Berakhlak terhadap lingkungan, adab terhadap lingkungan. ${ }^{27}$

Berdasarkan Muatan nilai tawadhu' yang ada di MI Ma'arif Mangunsari dalam pelajaran akidah akhlak, diharapkan kepada semua peserta didik MI Ma'arif Mangunsari untuk menerapkan nilai tawadhu' bersikap rendah hati, mempunyai adab sopan santun kepada orang tua maupun bapak ibu guru baik di madrasah maupun dirumahnya masingmasing sehingga para peserta didik memiliki kebiasaan-kebiasaan yang baik yang diterapkan pada perbuatan atau amaliahnya. Nilai yang diterapkan seperti adab tata krama ke sesama teman menghormati orang lain, membiasakan berakhlak yang baik seperti yang disampaikan oleh guru akidah akhlak bapak SBQ sebagai berikut:

"ya gini mas kalau dalam materi itu ada materi materi yang berkaitan dengan nilai tawadhu dikelas 4 itu ada materi banyak mas, contohnya adab kepada tetangga, hormat dan patuh kepada guru, saling tolong menolong yang mengedepankan akhlak, saya berharaphendaknya para peserta didik selalu mengedepankan sikap saling menghormati satu sama lain, bisa rendah hati tidak

\footnotetext{
${ }^{25}$ Bahren Ahmadi, Buku Siswa Akidah Akhlak Pendekatan Saintiflk Kurikulum 2013 Kelas 5, Jakarta: Kementerian Agama, 2014.

${ }^{26}$ Ridho, Miftakhur. Buku Siswa Akidah Akhlak Pendekatan Saintiflk Kurikulum 2013 Kelas 5, Jakarta: Kementerian Agama, 2015.

27 Sadi, Buku Siswa Akidah Akhlak Pendekatan Saintiflk Kurikulum 2013 Kelas 6, Jakarta: Kementerian Agama Republik Indonesia, 2016.
} 
memandang remeh dengan teman sebayanya, tidak mengejek atau menghina ke teman yang lainnya, sehingga akan tercipta suasana sekolah yang kondusif”. ${ }^{28}$

Nilai-nilai positif atau kebiasaan yang baik khususnya yang berkaitan dengan akhlak tata krama sopan santun memang sangat penting untuk membentuk karakter peserta didik yang tidak hanya berwawasan luas tapi juga berakhlak mulia.

\section{Proses Pembiasaan yang ditanamkan Guru Untuk Membentuk Sikap Tawadhu di} Kelas Atas MI Ma'arif Mangunsari

Nilai tawadhu di madrasah sangat berkaitan dengan pengelolaan madrasah. Pengelolaan yang dimaksud adalah bagaimana membentuk karakter direncanakan dilaksanakan dan dikendalikan dalam kegiatan-kegiatan pendidikan di madrasah yang memadai. Pengelolaan tersebut antara lain, nilai-nilai yang ditanamkan, muatan materi pembelajaran dalam kurikulum, pembelajaran, penilaian, pendidik dan tenaga kependidikan serta komponen terkait lainnya. Dengan demikian pengelolaan di madrasah merupakan media yang efektif dalam pembentukan nilai-nilai tawadhu. Dalam tataran madrasah kriteria pencapaian pembentukan karakter peserta didik yang berasas nilai-nilai tawadhu adalah dengan terbentuknya budaya madrasah. Budaya madrasah yang dimaksud adalah perilaku, tradisi, kebiasaan sehari-hari dan simbol-simbol yang dipraktikan oleh semua warga madrasah. ${ }^{29}$

Proses pembiasaan untuk membentuk sikap tawadhu merupakan hal yang penting bagi peserta didik karena secara tidak langsung dapat mengamalkan dari pembelajaran akidah akhlak menjadi sikap dan tingkah laku di dalam madrasah maupun di kehidupannya. Hal ini tidak terlepas dari campur tangan guru sehingga dapat menginternalisasikan nilai tawadhu untuk diajarkan kepada peserta didik agar menjadi sikap dan tingkah laku yang baik.

Dengan adanya pembelajaran akidah akhlak diharapkan peserta didik itu dapat menginternaliasasikan nilai tawadhu dalam kehidupan sehari-hari, dapat menghormati

\footnotetext{
${ }^{28}$ Wawancara pada SBQ guru akidah akhlak MI Ma'arif Mangunsari pada tanggal 6 Februari 2020.

${ }^{29}$ Haryanto, Popo, "Membentuk Karakter Peserta Didik Melalui Pendidikan Berbasis Al-Qur'an. Jurnal Pendidikan Agama Islam, Volume 6 Nomor 4 (2017), 84.
} 
kepada orang lain, rendah hati, menghargai kepada sesama. Dari hasil wawancara kepada pihak lembaga sekolah terkait khususnya guru akidah akhlak peneliti menemukan strategi guru dalam proses pembiasaan nilai tawadhu kepada peserta didik mengenai nilai nilai tawadhu yang diajarkan di madrasah sebagaimana yang diutarakan oleh guru akidah akhlak kelas 4 dalam wawancara:

“ Nilai-nilai tawadhu yang kami ajarkan dimadrasah ini mengacu pada buku paket akidah akhlak kurikulum 2013 yaitu tentang hormat dan patuh kepada guru, menghargai orang lain, akhlak kepada diri sendiri, akhlak kepada orang lain dan akhlak kepada lingkungan. ${ }^{30}$

Sejalan dengan hasil observasi lapangan, peneliti juga mengamati beberapa kelas, pada pembelajaran akidah akhlak yang di ajarkan oleh guru akidah akhlak, peserta didik sangat antusias sekali dalam mengikuti pembelajaran dengan banyak diskusi antar teman, musyawarah sehingga peserta didik akan menghormati pendapat lainnya ketika teman mempresentasikan materi didepan peserta didik lainnya. ${ }^{31}$

Dari pernyataan diatas tentang strategi yang digunakan dalam proses pembiasaan sikap tawadhu' peserta didik, dengan menerapkannya dalam proses pembelajaran dikelas sehingga peserta didik diharapkan akan terbiasa dengan sikap tawadhu diluar kelas. Maka dari itu guru akidah akhlak tidak hanya sekedar mengajar pelajaran akidah akhlak namun juga mengajak peserta didik untuk belajar diluar kelas agar tidak jenuh, dalam meningkatkan gaya belajar peserta didik, yaitu belajar diluar kelas agar peserta didik mengekspresikan praktiknya.

Pembiasaan nilai tawadhu melalui pembelajaran akidah akhlak merupakan proses memasukkan nilai nilai tawadhu secara utuh kedalam hati peserta didik yang nanti tercermin pada sikap atau perilaku sehingga mereka berperilaku baik berakhlakul karimah. Dengan demikian dapat direalisasikan dalam kehidupan sehari-hari di madrasah maupun dalam kehidupan sehari-hari. Pembelajaran akidah akhlak yang diajarkan dimadrasah dapat menumbuhkan sikap tawadhu yakni saling hormat menghormati,

${ }^{30}$ Wawancara dengan bapak SBQ guru akidah akhlak kelas 4 pada tanggal 6 februari 2020.

${ }^{31}$ Hasil Observasi di MI Ma'arif Mangunsari Pada tanggal 10 Februari 2020. 
rendah hati satu sama lain, mempunyai etika sopan santun kepada orang tua, guru maupun dengan teman sebaya.

Pada proses pembiasaan untuk membentuk sikap tawadhu dalam pembelajaran akidah akhlak bahwa secara umum kepala madrasah selaku pimpinan tertinggi madrasah MI Ma’arif Mangunsari bekerjasama dengan guru mata pelajaran menginternalisasi nilai tawadhu dalam pelaksanaan kegiatan belajar mengajar. Hal ini dilakukan agar membentuk perilaku peserta didik yang hormat patuh kepada bapak ibu guru serta mempunyai sikap sopan santun, rendah hati, tidak merasa sombong. Sesuai dengan hasil wawancara dari kepala madrasah MI Ma'arif Mangunsari sebagai berikut:

"Pada proses internalisasi tawadhu sebetulnya mengarah pada menciptakan lingkungan madrasah yang warganya ramah, sopan, santun, dan bersahaja, untuk itu perlu ada dukungan dari berbagai pihak dari warga madrasah dalam menciptakan lingkungan tersebut. ${ }^{32}$

Hal ini juga senada dengan pernyataan dari Ibu FZ sebagai kurikulum :

"Untuk menginternalisasikan nilai tawadhu yang harus diperhatikan adalah gurunya terlebih dahulu, yaitu dengan cara menjadi guru yang bisa memberi teladan yang baik, menjadi guru dengan memberi tahu peserta didik, menjadi guru ulung dengan menjelaskan memperagakan mengilhami melalui pendekatan pedagogik" ramah" bukan marah". 33

Dalam hal ini perlu diperhatikan bahwa dalam upaya menciptakan lingkungan madrasah yang baik tentu perlu penanaman kepada peserta didik dimulai dari para pendidik terlebih dahulu untuk menciptakan lingkungan yang benuansa tawadhu. Dalam hal ini para pendidik membiasakan untuk menanamkan nilai tawadhu pada peserta didik yaitu dengan menerapkan metode pembiasaan.

${ }^{32}$ Wawancara dengan SR kepala madrasah MI Ma'arif Mangunsari salatiga tanggal 8 Februari 2020.

${ }^{33}$ Wawancara dengan FZ sebagai bagian kurikulum di MI Ma;'arif Mangunsari pada tanggal3 februari 2020. 
Metode pembiasaan yaitu mengulangi kegiatan yang baik berkali-kali karena dengan itu semua tindakan yang baik diubah menjadi kebiasaan dalam sehari-hari. Selain itu, mengintensifkan kegiatan juga termasuk dalam strategi pembiasaan yang dilakukan baik dikelas maupun dalam kelas pada proses pembelajaran akidah akhlak. Hal ini sejalan dengan wawancara yang jelaskan oleh Ibu SR :

"Pembelajaran akidah akhlak terdapat muatan nilai-nilai tawadhu yaitu dari hormat dan patuh kepada bapak ibu guru, akhlak kepada Allah, Akhlak kepada Sesama manusia, sopan santun saling menghargai itu semua dengan pembiasaan. Dimulai waktu pagi berjabat tangan dan mencium tangan guru saat datang ke madrasah, serta saling menyayangi dan menghargai teman". ${ }^{34}$

Dari hasil wawancara diatas, bahwa proses pembiasaan sikap tawadhu dapat ditanamkan melalui strategi pembiasaan. Dalam pembiasaan guru mengajarkan kepada peserta didik terlebih dahulu supaya dapat memahami apa yang telah disampaikan oleh guru ketika belajar dikelas, para peserta didik setelah diajarkan nilai-nilai tawadhu oleh guru agar bisa diaplikasikan dibiasakan dalam kehidupan sehari-hari sehingga akan terbentuk peserta didik yang mempunyai akhlak yang baik sopan santun, saling menghargai, hormat dan patuh kepada bapak ibu guru di madrasah.

Dalam upaya pembiasaan sikap tawadhu kepada peserta didik pihak madrasah membuat kegiatan kegiatan yang harus dilaksanakan oleh para peserta didik adapun kegiatannya antara lain:

1) Membaca do'a, membaca Al-qur'an serta membaca asmaul husna secara bersama sama dipagi hari sebelum pelajaran dimulai. Berdasarkan wawancara dengan Ibu kepala Madrasah beliau menjelaskan bahwa:

"Membaca doa, Alqur'an dan asmaul husna memang harus dilaksanakan dimulai awal pemeblajaran agar peserta didik senantiasa memulai pelajaran dengan berdoa terlebih dahulu serta memohon kepada Allah supaya diberi an ilmu

\footnotetext{
${ }^{34}$ Wawancara dengan SR guru akidah akhlak kelas 5 dan 6 MI Ma'arif Mangunsari pada tanggal 8 februari 2020.
} 
yang bermanfaat dan tidak lupa sebagai proses penanaman nilai nilai tawadhu agar setelah membaca alqur'an, asmaul husna hatinya menjadi lebih tenang dan lemah lembut kepada sesama". ${ }^{35}$

Dengan demikian pada pembiasaan nilai tawadhu tidak hanya dilakukan dalam pembelajaran tetapi sebelum pembelajaranpun sudah ditanamkan oleh bapak ibu guru di MI Ma'arif Mangunsari untuk mencetak generasi yang berakhlakul karimah.

2) Sholat berjama'ah khususnya sholat dhuhur dan sholat dhuha setiap hari pada masingmasing kelas untuk dilaksanakan dimusholla madrasah, adapun sholat jum'at dilaksanakan oleh peserta didik kelas 6 dan wajib untuk mengikuti sholat jum'at berjamaah dimasjid kampus 2 MI Ma'arif Mangunsari yang berada di ngawen.

Dari penjelasan diatas sebagian dari langkah yang diambil untuk menanamkan nilai tawadhu kepada peserta didik untuk senantiasa membiasakan sholat dhuhur berjamaah di musholla. ${ }^{36}$ Dengan adanya kegiatan tersebut diharapkan guru mampu menanamkan nilai tawadhu kepada peserta didik serta mencetak peserta didik yang berakhlakul karimah. Tujuan adanya kegiatan-kegiatan dalam upaya menanamkan nilai tawadhu kepada peserta didik adalah menjadikan peserta didik untuk inisiatif melakukan setiap kegiatan yang diterapkan di madrasah. Peserta didik menjadi terbiasa ntuk menerapkan kegiatan tersebut baik dimadrasah maupun dalam kehidupan sehari-hari di luar madrasah.

\section{Dampak dari Pembiasaan Nilai Tawadhu dalam Pembelajaran Akidah Akhlak Terhadap Perilaku Peserta Didik di Kelas Atas MI Ma'arif Mangunsari}

Sebuah proses yang dilakukan dalam pembelajaran oleh setiap pendidik ataupun guru pasti akan berdampak bagi yang melakukan kegiatan tersebut, baik itu dampak positif maupun dampak negatif. Dampak dari adanya proses pembelajaran yaitu pembiasaan sikap tawadhu tentunya cenderung pada dampak positif yang ditimbulkan karena nilainilai tawadhu merupakan nilai-nilai yang baik, penting dan diperlukan dalam kehidupan

${ }^{35}$ Hasil wawancara dengan SR Kepala MI Ma'arif Mangunsari pada tanggal 8 februari 2020.

${ }^{36}$ Hasil observasi pengamatan yang dilakukan peneliti selama melakukan penelitian pada tanggal 5 februari 2020. 
sehari-hari, secara asumtif dapat diketahui bahwa dampak positif merupakan hasil dari adanya tahapan-tahapan dalam internalisasi nilai tawadhu tersebut. Mengenai dampak dari pembiasaan sikap tawadhu dalam pembelajaran akidah akhlak terhadap perilaku peserta didik di Kelas Atas MI Ma'arif Mangunsari dapat dipaparkan dibawah ini berdasarkan data-data yang diperoleh dari madrasah. Adapun gambaran tentang dampak pembiasaan nilai tawadhu yang diajarkan dimadrasah sebagai berikut:

a. Sopan Santun

Pembiasaan nilai tawadhu kepada peserta didik berdampak pada peserta didik berbicara dengan bapak ibu guru dengan santun, mempunyai tata krama menghargai kepada orang yang lebih tua terlebih kepada gurunya yang telah mendidik di madrasah setiap hari. Hal ini sesuai dengan penjelasan dari guru akidah akhlak SBQ:

"Mengajarkan menanamkan dimadrasah nilai tentang kesopanan, adab kepada teman sebaya menghormati satu sama lain agar anak itu sejak dini sudah mengetahui dan mengamalkan membiasakan kelak nantinya tumbuh dewasa sudah terbiasa dengan sendirinya untuk senantiasa berbuat baik kepada sesama manusia". ${ }^{37}$

Dari penjelasan diatas sejalan dengan sikap peserta didik setelah diajarkan oleh guru mengenai nilai nilai tawadhu berikut penjelasan dari RA peserta didik kelas 4:

"Pendapat saya mengenai nilai tawadhu bagus pak ketika diajarkan kepada peserta didik karena diajarkan hormat dan patuh kepada guru sehingga akan membentuk perilaku yang baik". 38

Dari wawancara diatas dapat diketahui bahwa menanamkan nilai tawadhu dapat membentuk perilaku peserta didik dan menjadi berakhlakul karimah.

b. Rendah hati

\footnotetext{
${ }^{37}$ Hasil wawancara dengan Sbq sebagai guru akidah akhlak kelas 4 MI Ma'arif Mangunsari pada tanggal 6 februari 2020.

${ }^{38}$ Hasil wawancara dengan RA peserta didik kelas 4 MI Ma'arif Mangunsari pada tanggal 6 februari 2020.
} 
Penanaman nilai tawadhu yang diupayakan untuk membentuk sikap dan perilaku peserta didik yang baik yaitu rendah hati, tidak sombong dan akrab kepada peserta didik lainnya atau teman sejawat teman sekelas. Hal ini yang ditemukan ketika observasi dikelas, ada salah satu peserta didik yang sakit ketika melihat temannya yang sakit dia membantu temannya untuk langsung diantar ke UKS atau dengan tanggap dia mengambilkan obat untuk temannya yang sedang sakit. ${ }^{39} \mathrm{Hal}$ ini sesuai dengan yang dijelaskan oleh peserta didik kelas 5 bernama MT sebagai berikut:

"Saya sangat senang dengan teman teman saya yang ada dikelas 5 karena orangnya tidak sombong bisa cepat diajak bergaul, satu sama lain saling akrab, saling membantu ketika ada teman yang sedang kesusahan segera dibantu dengan teman teman yang lain". ${ }^{40}$

Dengan pemaparan diatas bahwa peserta didik di MI Ma'arif Mangusari telah menerapkan rendah hati tidak saling sombong satu sama lain sehingga antara peserta didik satu dengan yang lain bisa saling bekerja sama dalam hal kebaikan.

c. Hormat dan patuh kepada nasihat guru

Nilai tawadhu yang di internalisasikan kepada peserta didik dengan strategi keteladanan, pembiasaan, akan berdampak pada diri peserta didik, perilaku yang ditunjukan salah satunya dengan bagaimana para peserta didik menghormati dan patuh kepada nasihat guru. Berkata dan berucap dengan perkataan yang baik. Hal ini disampaikan oleh ibu SR selaku kepala madrasah dan sebagai guru akidah akhlak kelas 5 dan 6:

"Sikap peserta didik dalam menghormati guru sangat baik dibuktikan dengan setiap hari para peserta didik mengikuti pembelajaran didalam kelas dan diluar kelas, sangat antusias dibuktikan dengan setiap pagi para peserta didik berjabat tangan dengan mencium tangan bapak ibu guru dan berjabat tangan dengan teman lainnya sehingga akan tertanam pada peserta didik

\footnotetext{
${ }^{39}$ Hasil observasi proses pembelajaran akidah akhlak di kelas 5 MI Ma'arif Mangunsari 5 Februari 2020.
}

${ }^{40}$ Wawancara dengan MT peserta didik MI Ma'arif Mangunsari kelas 5 pada tanggal 6 februari 2020. 
secara tidak langsung untuk senantiasa menghormati kepada yang lebih tua dan menghargai kepada teman sebaya". ${ }^{41}$

Dengan hormat dan patuh kepada guru akan timbul bagi peserta didik sikap yang baik dan menjadi suri tauladan bagi teman-temannya dan diharapkan dilakukan dalam kehidupan sehari-hari baik di madrasah maupun di rumah atau lingkungan masyarakat.

d. Rajin belajar

Penanaman nilai tawadhu kepada peserta didik berdampak dengan peserta didik rajin belajar dari apa yang telah diajarkan dalam proses pembelajaran. Hal ini senada dengan penjelasan dar JBS peserta didik kelas 6:

"Ketika guru menjelaskan materi serta ketika ada diskusi dan prensentasi di kelas peserta didik menghargai teman lainnya dan menyimak penjelasan dari peserta didik maupun guru setelah itu guru mengimbau untuk senantiasa rajin belajar agar nilainya baik dan akhlaknya juga baik. Serta diluar kelas terbiasa melaksanakan ibadah seperti sholat dhuhur sholat dhuha berjamaah dengan didampingi oleh guru." 42

Dari penjelasan diatas bahwa peserta didik senantiasa rajin belajar dalam proses pembelajaran maupun di luar pembelajaran hai ini dibuktikan dengan terbiasa melaksanakan ibadah sholat dhuha, sholat dhuhur berjamaah, pembacaan asmaul husna, hafalan surat-surat pendek. Hal ini sesuai dengan penjelasan guru akidah akhlak bahwa sebelum pembelajaran dimulai semua peserta didik melakukan sholat dhuha, pembacaan asmaul husna dan diakhiri dengan pembacaan surat-surat pendek.

Dampak dari pembiasaan nilai tawadhu dalam pembelajaran akidah akhlak terhadap perilaku peserta didik di MI Ma'arif Mangunsari merupakan hal positif

${ }^{41}$ Wawancara kepada ibu SR Kepala MI Ma'arif Mangunsari sekaligus guru akidah akhlak kelas 5 dan 6 pada tanggal 8 Februari 2020.

${ }^{42}$ Wawancara dengan JBS Peserta didik MI Ma'arif Mangunsari kelas 6 pada tanggal 6 Februari 2020. 
yang diharapkan tumbuh dan berkembang menjadi sikap keseharian peserta didik di kelas, di luar kelas maupun dalam kehidupan sehari-hari. Dampak yang tercermin dari pembiasaan nilai tawadhu adalah:

1) Sopan santun

Pembiasaan nilai tawadhu kepada peserta didik berdampak pada peserta didik berbicara dengan bapak ibu guru dengan santun, mempunyai tata krama menghargai kepada orang yang lebih tua terlebih kepada gurunya yang telah mendidik di madrasah setiap hari.

Berdasarkan dengan hasil temuan penelitian, dampak pembiasaan nilai tawadhu dalam pembelajaran akidah akhlak terhadap perilaku peserta didik terlihat dalam pembelajaran guru telah mengajarkan menanamkan nilai tawadhu di madrasah tentang kesopanan, adab kepada teman sebaya menghormati satu sama lain agar anak itu sejak dini sudah mengetahui dan mengamalkan membiasakan kelak nantinya tumbuh dewasa sudah terbiasa dengan sendirinya untuk senantiasa berbuat baik kepada sesama manusia.

2) Rendah hati

Pembiasaan nilai tawadhu yang diupayakan untuk membentuk sikap peserta didik yang baik yaitu rendah hati, tidak sombong dan akrab kepada peserta didik lainnya atau teman sejawat teman sekelas baik di dalam kelas maupun di luar kelas untuk senantiasa bersikap rendah hati kepada peserta didik lainnya.

Berdasarkan hasil penelitian di MI Ma'arif Mangunsari bahwa guru akidah akhlak sudah mengajarkan nilai tawadhu biasanya menjelaskan terlebih dahulu dan mencontohkan dengan contoh yang baik, kemudian disuruh membiasakan bersikap sopan, rendah hati kepada orang lain contohnya setiap mau pelajaran peserta didik disuruh bersalaman kepada guru, ketika pelajaran dikelas ada diskusi teman lain mendengarkan teman yang menyampaikan pendapat, saling menghargai kepada teman lain dan menolong apabila sedang 
mengalami kesulitan. Dalam hal ini sudah terlihat bahwa peserta didik sudah menerapkan sikap rendah hati kepada sesama.

3) Hormat dan patuh kepada nasihat guru

Sikap tawadhu yang di internalisasikan kepada peserta didik dengan pembiasaan, akan berdampak pada diri peserta didik, perilaku yang ditunjukan salah satunya dengan bagaimana para peserta didik menghormati dan patuh kepada nasihat guru.

Berdasarkan dari hasil penelitian bahwa di MI Ma'arif Mangunsari menanamkan nilai tawadhu dengan hormat dan patuh kepada bapak ibu guru, mendengarkan nasihat-nasihat guru baik di dalam pembelajaran dikelas maupun di luar kelas artinya dalam lingkungan madrasah.

4) Rajin Belajar

Pembiasaan nilai tawadhu kepada peserta didik di MI Ma'arif Mangunsari berdampak dengan peserta didik rajin belajar dari apa yang telah diajarkan dalam proses pembelajaran dibuktikan dengan terbiasa melaksanakan ibadah sholat dhuha, sholat dhuhur berjamaah, pembacaan asmaul husna, hafal surat surat pendek. Pada MI Ma'arif Mangunsari faktor pendorongnya adalah adanya TPQ pagi dengan menggunakan metode qiroati dilanjutkan dengan sholat dhuha berjamaah setiap kelas, faktor pendorongnya Di MI Ma'arif Mangunsari dimulai dari pembacaan surat-surat pendek diikuti dengan sholat dhuha berjamaah dan melaksanakan ibadah secara berjamaah di masjid terdekat. Sehingga madrasah tersebut mempunyai ciri khas dalam menanamkan nilai tawadhu kepada peserta didik.

Berdasarkan dampak pembiasaan nilai tawadhu dalam pembelajaran akidah akhlak yang telah telah muncul kepada peserta didik ada empat karakter di MI Ma'arif Mangunsari yaitu sopan santun, rendah hati, hormat dan patuh kepada bapak ibu guru, rajin belajar serta terbiasa melaksanakan ibadah dan nilai yang 
belum muncul pada madrasah tersebut berdasarkan indikator tawadhu adalah berpakaian rapi, sederhana, dan suka menolong.

\section{E. Kesimpulan}

1. Muatan nilai tawadhu dalam pembelajaran akidah akhlak di kelas atas adalah di kelas 4 peserta didik muatan materinya adalah indahnya berperilaku terpuji 1 (hormat dan patuh kepada orang tua dan guru), indahnya berperilaku terpuji 2 (tabah dan sabar dalam menghadapi cobaan melalui kisah siti masyitoh), Asmaul husna (As-salam, Al-Latif) yang mana mengajarkan peserta didik untuk membiasakan mengucapkan salam serta bersikap ramah, lemah lembut dalam bertutur kata dengan orang tua, guru, teman dan antara sesama. Indahnya berperilaku terpuji 4 (berperilaku terpuji ketika bertamu dan berperilaku terpuji terhadap teman dalam kehidupan sehari-hari). Sementara itu muatan materi kelas 5 yang berkaitan dengan nilai tawadhu' yaitu mari membina keharmonisan dengan tetangga dan masyarakat yang menjelaskan tentang menghormati tetangga, saling menyayangi, hidup bermasyarakat yang baik dengan mengedepankan sikap lemah lembut, memupuk sikap toleransi hormat menghormati dengan seluruh anggota masyarakat. Untuk materi kelas 6 ada materi tentang Indahnya melantunkan kalimat toyyibah (istighfar), mengenal Allah melalui asmaul husna (Al-ghafur, Al-Afwu, Assabur, Al-Halim), Berakhlak terhadap lingkungan, adab terhadap lingkungan.

2. Pembiasaan yang ditanamkan guru untuk membentuk sikap tawadhu peserta didik di MI Ma'arif Mangunsari adalah guru membiasakan bersama peserta didik dengan membaca Alquran, membaca Asmaul husna, serta sholat dhuha dan dhuhur secara berjamaah dengan mengutamakan sikap tawadhu yaitu membiasakan sopan santun, hormat dan patuh kepada guru rendah hati antar sesama .

3. Dampak dari pembiasaan nilai tawadhu dalam pembelajaran akidah akhlak di kelas atas MI Ma'arif Mangunsari tercermin dalam sikap peserta didik di madrasah tersebut di dalam kelas maupun di luar kelas, antara lain: a) Sopan santun, b) Rendah hati, c) hormat dan patuh kepada bapak ibu guru dan orang tua, d) Rajin belajar dan terbiasa melakukan 
ibadah. Yang belum ditemukan dalam proses internalisasi nilai tawadhu adalah saling menolong, hormat kepada orang tua, berpakaian rapi dan sederhana.

\section{Daftar Pustaka}

Al-Hasyim Abdul Muneim. Akhlak Rasul Menurut Bukhari Muslim, Jakarta: Gema Insani, 2009.

Amrul Khalid. Semulia Akhlak Nabi, Solo: Aqwam, 2006.

Ansori, Ahmad Muhajir Strategi. Penanaman Nilai-nilai Pendidikan Islam Pada Peserta Didik, Jurnal Pusaka Media Kajian dan Pemikiran Islam LP3I IAI Al-Qolam, (2016) 8.

Arikunto, Suharsimi. Prosedur Penelitian. Jakarta: Bina Aksara,1998.

Armai, Arief. Pengantar Ilmu dan Metodologi Pendidikan Islam, Jakarta: Ciputat Pers, 2002.

Asren Nasution, Membangun Karakter Bangsa Bercermin pada Sosok Jenderal Besar Soedirman, Jakarta: Prenada, 2012.

Bahren Ahmadi, Buku Siswa Akidah Akhlak Pendekatan Saintiflk Kurikulum 2013 Kelas 4, Jakarta: Kementerian Agama, 2014.

Emzir. Metodologi Penelitian Pendidikan Kuantitatif \& Kualitatif, Jakarta: PT. Raja Grafindo Persada, 2010.

Fachri, Moch. "Urgensi Pendidikan Agama Islam dalam Pembentukan KarakterBangsa", Atturas, Volume 1, Number 1 (Januari-Juni 2014).

Faqih, Khaerul, Nilai-nilai Pendidikan Akhlak dan Tasawuf dalam Kitab Nashoihul Ibad Karya Syaikh Nawawi Albantani dan Implementasinya pada Pondok Pesantren Tradisional, Jurnal Aksioma Ad-Diniyah, Vol. 6, No. 2, 2018.

Haryanto, Popo, "Membentuk Karakter Peserta Didik Melalui Pendidikan Berbasis Al-Qur'an. Jurnal Pendidikan Agama Islam, Volume 6 Nomor 4 (2017). 
Ilyas, Yunahar, Kuliah Aqidah, Yogyakarta: Lembaga Pengkajian dan Pengalaman Islam LPPI, 2000.

Ilyas, Yunahar, Kuliah Akhlaq, Yogyakarta: Lembaga Pengkajian dan Pengamalan Islam LPPI, 2001 .

Miftakhur Ridho, Buku Siswa Akidah Akhlak Pendekatan Saintiflk Kurikulum 2013 Kelas 5, Jakarta: Kementerian Agama, 2015.

Moleong, Lexy J. Metodologi Penelitian Kualitatif, Bandung: PT. Remaja Rosda Karya, 2010.

Moleong, Lexy J. Metodologi Penelitian Kualitatif, Bandung: PT. Remaja Rosda Karya, 2013.

Munif, Muhammad. Strategi Internalisasi Nilai-Nilai PAI Dalam Membentk Karakter Siswa, Edureligia, Vol. 01 No. 01 Tahun 2017.

Nasirudin, Akhlak Pendidik Upaya Membentuk Kompetensi Spiritual dan Sosial, Semarang: CV Karya Abadi Jaya, 2015.

Sabarisman, Muslim Nunung Unayah, Fenomena Kenakalan Remaja dan Kriminalitas The Phenomenon Of Juvenili Delinquency And Criminality, Sosio Informa, Vol 1, No. 02, MeiAgustus, 2015.

Sadi, Buku Siswa Akidah Akhlak Pendekatan SaintifIk Kurikulum 2013 Kelas 6, Jakarta: Kementerian Agama Republik Indonesia, 2016.

Sukandarrumidi, Metodologi Penelitian Praktis, Yogyakarta: Teras, 2006, 100-101.

Sumaedi, Sahadi, Dadan Sumara, Meilani Budiarti Santoso, Kenakalan Remaja dan Penanganannya. Jurnal Penelitian dan PPM, Vol. 4, No. 2, 2017.

Syamsuddi Sahiron (ed), Metodologi Penelitian Qur'an dan Hadis, Yogyakarta:TH Press, 2007.

Syekh ahmad ibnu Athaillah dalam purnama Rozak, Indikator tawadhu dalam keseharian, Jurnal Madaniyah, Volume 1 Edisi XII, Januari 2018. 
Tobroni, Imam Suprayogo. Metodologi Penelitian Sosiologi-Agama, Cet. II, Bandung: PT. Remaja Rosdakarya, 2003.

Zulnuraini. Pendidikan Karakter, "Konsep, Implementasi Dan Pengembangannya di Sekolah Dasar Di Kota Palu” Jurnal DIKDAS, Vol.1, No 1, September 2012. 